\title{
Bezpieczna przestrzeń akustyczna w parku zdrojowym w oparciu o jego plan zagospodarowania
}

\author{
Małgorzata Sztubecka1, Maria Mrówczyńska², \\ Anna Bazan-Krzywoszańska², Marta Skiba² \\ ${ }^{1}$ Uniwersytet Technologiczno-Przyrodniczy w Bydgoszczy, Wydział Budownictwa, \\ Architektury i Inżynierii Środowiska, Al. Prof. S. Kaliskiego 7, 85-796 Bydgoszcz \\ ${ }^{2}$ Uniwersytet Zielonogórski, Wydziat Budownictwa, Architektury i Inżynierii Środowiska, \\ ul. Licealna 9, 65-417 Zielona Góra, Polska
}

\begin{abstract}
Streszczenie: Obszarami zagrożonymi wystąpieniem jednego z najbardziej uciążliwych czynników środowiskowych, jakim jest hałas, są tereny działalności człowieka. Uciążliwość ta, w szczególności dotyczy aglomeracji miejsko - przemysłowych. Hałas ma ujemny wpływ na zdrowie ludzi, zmniejsza wydajność pracy, utrudnia wypoczynek i niekorzystnie wpływa na koncentrację. Wskaźnikiem hałasu, jego natężenia, jest logarytmiczna miara poziomu dźwięku wyrażona w decybelach (dB). W zależności od funkcji i przeznaczenia danego terenu, prawo określa dopuszczalne wartości poziomów hałasu. Zawierają się one w przedziale tak zwanego komfortu akustycznego.

Właściwa lokalizacja i ukształtowanie przestrzeni terenów zielonych ma niewątpliwy wpływ na komfort wypoczynku, a dokumenty planistyczne, jako prawo lokalne, wskazując na przeznaczenie takich obszarów, stanowią podstawę ich programu użytkowego i zagospodarowania. Odpowiednie zapisy miejscowego planu zagospodarowania przestrzennego pozwalają na racjonalne ukształtowanie przestrzeni. Celem artykułu jest zwrócenie uwagi na problem hałasu, występujący poza przedziałem odczuwalnego komfortu oraz ocena możliwości, jakie oferują tego typu dokumenty w odniesieniu do istniejących notacji, pod względem bezpieczeństwa akustycznego osób przebywających na tych terenach.
\end{abstract}

Słowa kluczowe: przestrzeń akustyczna, kształtowanie środowiska, hałas, teren zielony, miejscowy plan zagospodarowania

\section{Wprowadzenie}

Przestrzeń zurbanizowaną, traktuje się jako ogół zasobów życiowych bezpośrednio wykorzystywanych przez mieszkańców. Warunki w niej występujące decydują także o możliwościach osiedlania się człowieka, który w mniejszym lub większym stopniu, wprowadza w przestrzeni zmiany ilościowe i jakościowe. Zanieczyszczenie środowiska hałasem miejskim stopniowo rośnie, głównie z powodu postępującej industrializacji i urbanizacji. Wiele badań i raportów odnosi się do faktu, że hałas negatywnie wpływa na fizjologiczne i psychiczne zdrowie człowieka [Marquis-Favre i inni, 2005; Honga, Jeon, 2017], a środowisko dźwiękowe jest uważane za kluczowy czynnik w tworzeniu zdrowego miasta [Corburn 2009; Seidman i Standring, 2010]. Aby zapobiec pogarszaniu się jakości przestrzeni, również pod względem akustycznym, wprowadza się różnorodne formy ochrony przed szkodliwym wpływem tego rodzaju zanieczyszczeń. Opisanych problemów dotyczy między innymi Dyrektywa 2002/49/WE Parlamentu Europejskiego i Rady z dnia 25 czerwca 2002 r. odnosząca się do oceny i zarządzania poziomem hałasu w środowisku, wskazując że niezbędnym jest przyjęcie wspólnych metod oceny "hałasu w środowisku" i definicji "wartości granicznych" w kategoriach zharmonizowanych wskaźników, stużących ustalaniu poziomu hałasu. Za wskaźniki hałasu uznano LDEN dla oceny dokuczliwości i LN dla oceny zakłócenia snu. Dyrektywa wprowadza też obowiązek realizacji map hałasu, w celu tworzenia obrazu postrzegania poziomu hałasu danego obszaru. Konsekwencją tworzenia ww. map jest plan działań, mających na celu zapobieganie 
powstawaniu źródeł hałasu, ale także obniżenie jego poziomu tam, gdzie wymaga tego środowisko, głównie w związku ze szkodliwym oddziaływaniem na ludzi oraz ochronę klimatu akustycznego środowiska, tam gdzie jest on jeszcze właściwy.

Mapa zanieczyszczenia hałasem może być przydatnym narzędziem wykorzystywanym w projektowaniu i planowaniu urbanistycznym, ponieważ dostarcza informacje odzwierciedlające postrzeganie akustyczne. W literaturze przyjęło się, że mapa przestrzeni akustycznej może zawierać trzy różne tematy: mapę źródeł dźwięku, mapę psychoakustycznego odbioru oraz odczuwalnej jakości środowiska dźwiękowego [Aletta i Kang, 2015; Genuit i Fiebig, 2006; Genuit i inni, 2008; Hao i inni, 2015; Liu i inni, 2013, 2014].

Mapa źródłeł dźwięku dostarcza informacji na temat różnych rodzajów hałasu, w tym także pozytywnych. Liu i inni $[2013,2014]$ opracował mapę postrzegania źródeł dźwięku w oparciu o zmienność przestrzenno czasową. Zakwalifikował źródła jako: antropologiczne, biologiczne i geograficzne oraz wykazał, że są one charakterystyczne dla krajobrazu miejskich przestrzeni i zależne od ich kompozycji.

Kształtowanie przestrzeni, pod względem akustycznym, jest postępowaniem opartym na formowaniu warunków akustycznych tak, aby bodźce dźwiękowe nie przekraczały dopuszczalnych wartości i były optymalne z punktu widzenia potrzeb zdrowia oraz działalności człowieka. Powinny gwarantować tworzenie sprzyjających warunków funkcjonowania i zachowanie tzw. komfortu akustycznego. Szkodliwe oddziaływanie hałasu na organizm człowieka jest problemem złożonym i dotyczy wielu jego przestrzennych aktywności. Stwierdzenie to potwierdza schemat opisujący skutki oddziaływania hałasu na sfery aktywności człowieka (Rys. 1).
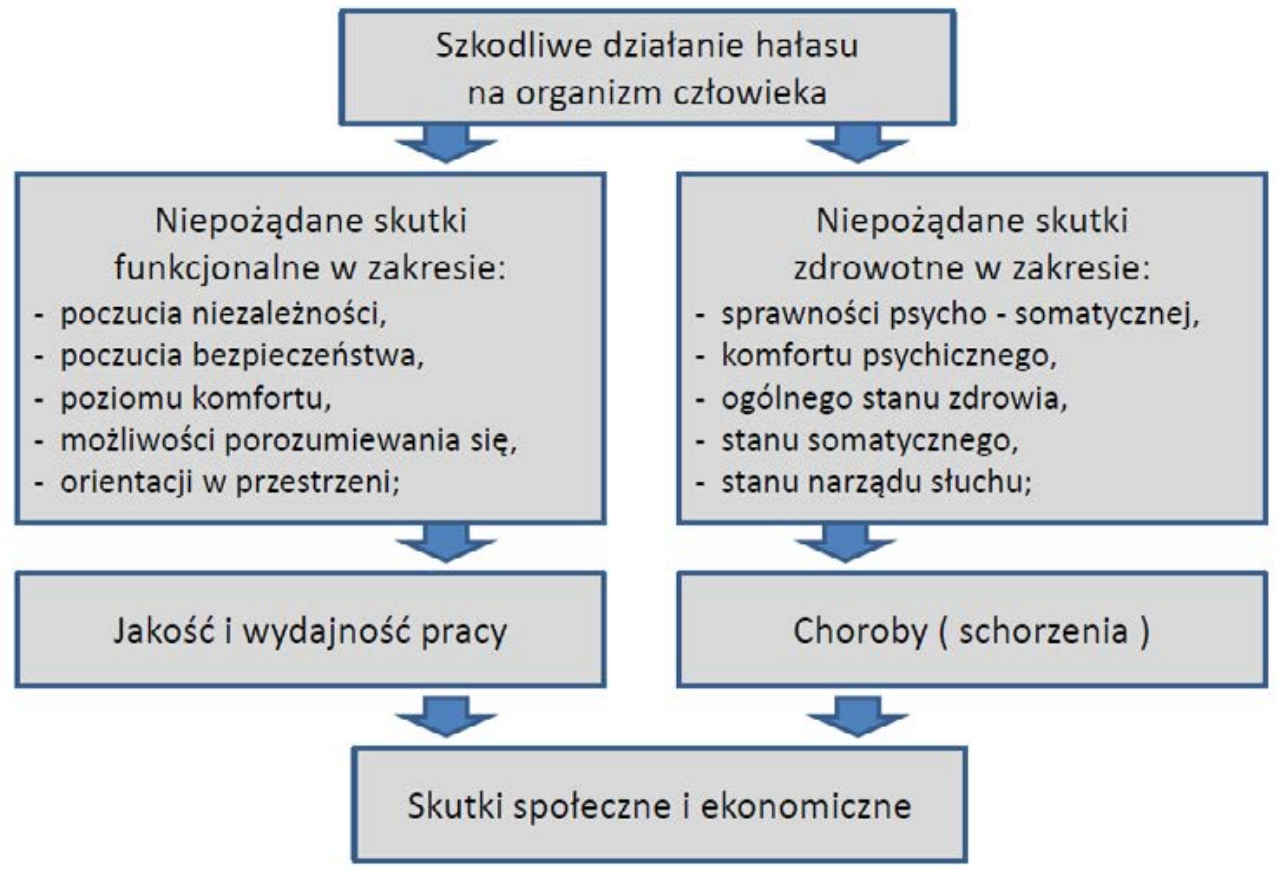

Ryc. 1. Wpływ hałasu na organizm człowieka [Engel, 2001]

Subiektywne odczucie i wrażliwość człowieka na hałas zależy od jego fizjologicznych predyspozycji oraz charakterystyki samego dźwięku. Określone dźwięki mogą jednocześnie powodować wrażenia przyjemne, jak i stanowić uciążliwość. Wynika to z indywidualnych cech każdego człowieka, jego wieku, stanu zdrowia, nastroju oraz wrażliwości i odporności psychicznej. Oprócz tego, dokuczliwość hałasu wzrasta, jeśli pojawi się on niespodziewanie i z niewiadomego źródła. Stwierdzono też, iż inaczej odbierany jest dźwięk przez jego sprawcę, a inaczej przez jego odbiorcę. Uwzględniając różną szkodliwość hałasu dla zdrowia człowieka, Lipowczan [Lipowczan, 2001] dokonał rozróżnienia jego oddziaływania w zależności od wartości równoważnego poziomu dźwięku $\mathrm{L}_{\text {Aeq }}$ (Tabela 1). 
Tabela 2. Oddziaływanie hałasu na organizm człowieka [Lipowczan, 2001]

\begin{tabular}{|c|c|c|}
\hline Lp. & $\begin{array}{l}\text { Równoważny po- } \\
\text { ziom dźwięku } \mathrm{L}_{\text {Aeq }}\end{array}$ & Wpływ na organizm ludzki \\
\hline 1 & od około 0 do $20 \mathrm{~dB}$ & $\begin{array}{l}\text { Przedziat dyskomfortu - stan określany potocznie jako „cisza, wywołująca } \\
\text { dzwonienie w uszach". Przy dłuższym działaniu, zwłaszcza w samotności, } \\
\text { powoduje odczucie izolacji, wyobcowania, itp. }\end{array}$ \\
\hline 2 & $\begin{array}{c}\text { od } 20 \\
\text { do około } 55 \mathrm{~dB}\end{array}$ & $\begin{array}{c}\text { Przedział komfortu - w organizmie uruchamiane są procesy regeneracji } \\
\text { odczuwane świadomie, jak i podświadomie. Przedział ten obejmuje dźwięki } \\
\text { przyrody (głos ptaków, szum liści, płynąca woda). }\end{array}$ \\
\hline 3 & $\begin{array}{l}\text { od około } 55 \\
\text { do } 85 \mathrm{~dB}\end{array}$ & $\begin{array}{c}\text { Przedziat narażenia - organizm zaczyna uruchamiać mechanizmy obronne. } \\
\text { Narażone osoby zaczynają odczuwać niekorzystny wpływ hałasu. } \\
\text { W tym przedziale mieszczą się niektóre wartości dopuszczalne ze względu na } \\
\text { rodzaj wykonywanej pracy. }\end{array}$ \\
\hline 4 & $\begin{array}{l}\text { od około } 85 \\
\text { do } 120-135 \mathrm{~dB}\end{array}$ & $\begin{array}{l}\text { Przedziat zagrożenia - górne wartości poziomu dźwięku określane są jako } \\
\text { „próg bólu”. }\end{array}$ \\
\hline
\end{tabular}

Światowa Organizacja Zdrowia (WHO) definiuje hałas w środowisku jako „hałas emitowany ze wszystkich źródeł z wyjątkiem hałasu przemysłowego" [World Health Organization Guidelines for Community Noise. 2000, in: WHO-Expert Task Force Meeting, Held in London, UK]. Natomiast Dyrektywa 2002/49/WE definiuje hałas jako "niepożądane lub szkodliwe dźwięki, powodowane przez działalność człowieka, w tym: hałas drogowy, kolejowy, lotniczy i od zakładów przemysłowych". Określenia te odnoszą się do dźwięków wywoływanych przez człowieka lub urządzenia sterowane przez człowieka. W Polsce wymagania w zakresie ochrony środowiska przed hałasem określa ustawa z dnia 27 kwietnia 2001 r. - Prawo ochrony środowiska (Dz. U. z 2016 r. poz. 672, 831, $903,1250,1427)$. Aktem wykonawczym do powyższej ustawy jest obwieszczenie Ministra Środowiska z dnia 15 października 2013 r. w sprawie ogłoszenia jednolitego tekstu rozporządzenia Ministra Środowiska w sprawie dopuszczalnych poziomów hałasu w środowisku (Dz. U. z 2014, poz. 112). Wyróżnione są w nim: strefa ochronna "A" uzdrowiska, tereny szpitali poza i w miastach, tereny zabudowy mieszkaniowej jednorodzinnej, wielorodzinnej i zamieszkiwania zbiorowego, tereny związane ze stałym lub wielogodzinnym przebywaniem dzieci, tereny domów opieki społecznej, tereny zabudowy zagrodowej, tereny mieszkaniowo - usługowe, tereny w strefie śródmiejskiej miast powyżej 100 tys. mieszkańców, a także tereny rekreacyjno-wypoczynkowe. Rozporządzenie to określa także dopuszczalne poziomy hałasu na wyżej wymienionych obszarach w określonym przedziale czasowym dnia i nocy.

\section{Strefy zieleni w mieście}

Strefy funkcjonalne miasta odpowiadają różnym strefom aktywności jego mieszkańców. Każda z nich charakteryzuje sie innymi źródłami, poziomem oraz wpływem hałasu na zdrowie. W każdej z nich hałas jest inaczej postrzegany [Votsi i inni, 2012; Przesmycka, 2015].

Parki, jako jeden z ważnych składników środowiska przyrodniczego i kulturowego, są obszarami o szczególnym znaczeniu dla zaspokojenia potrzeb mieszkańców, poprawy jakości ich życia. Sprzyjają nawiązywaniu kontaktów społecznych ze względu na swoje położenie oraz cechy funkcjonalno-przestrzenne. W większych obszarowo parkach występuje bogaty program funkcjonalny - nagromadzenie, obok siebie, różnych funkcji. Obok strefy ciszy i spacerowej może pojawić się strefa sportowa lub zabawowa [Sztubecka, Skiba, 2016]. Czasem trudno oddzielić od siebie różne funkcje, a wprowadzanie sztucznych przegród oddzielających nie zawsze jest rozwiązaniem właściwym. Dotyczy to także wzajemnego przenikania hałasów. Formą, pozwalającą na oddzielenie obszarów cichych od obszarów głośniejszych jest ekranowanie akustyczne, stanowiące rodzaj ochrony przed hałasem. W tym celu można wykorzystać naturalne i sztuczne elementy urbanistyczne.

Do naturalnych elementów ochrony przed hałasem można zaliczyć:

- elementy dźwiękochłonno- rozpraszające (zieleń), 
- elementy ekranizujące (nasypy, wykopy, ukształtowanie terenu),

- elementy dźwiękochłonno-odbijająco-ekranizujące (nasypy pokryte zielenią) [Engel, 2001].

Do pożądanych sposobów obniżania hałasu i rozpraszania energii akustycznej należą naturalne ekrany. Efektywność ich jest jednak mała, wynika z ograniczonego tłumienia hałasu przez drzewa i krzewy. Zieleń w okresie wegetacji redukuje poziom hałasu od 0,03 do 0,35 dB na $1 \mathrm{~m}$ szerokości przegrody, natomiast w stanie bezlistnym od 0,01 do 0,20 dB.

Większą skuteczność ochrony przed hałasem na otwartej przestrzeni mają sztuczne ekrany akustyczne. Zastosowanie takich przegród na terenach parkowych wymaga odpowiedniego ukształtowania krajobrazu. $\mathrm{Na}$ otwartej przestrzeni i w zespołach parkowych ekrany powinny być wykonane z naturalnych materiałów takich jak: drewno, kamień, cegła, zieleń.

Szczególnym rodzajem terenów zielonych są parki zdrojowe. Są one częścią uzdrowisk i z tego względu podlegają regulacjom zapisanym w ustawie z dnia 28 lipca 2005 r. o lecznictwie uzdrowiskowym, uzdrowiskach i obszarach ochrony uzdrowiskowej oraz o gminach uzdrowiskowych (Dz. U. z 2016 r. poz. 879, 960), a także w polskiej normie „Uzdrowiska”. Termin „uzdrowisko" stanowi połączenie na swoim obszarze funkcji leczniczej i wypoczynkowej. Podstawą działalności na tych terenach jest zachowanie równowagi pomiędzy elementami środowiska przyrodniczego i kulturowego. Parki uzdrowiskowe, stanowią strefę ochrony uzdrowiskowej - wydzieloną część obszaru uzdrowiska, mające na celu ochronę czynników leczniczych i naturalnych surowców leczniczych, walorów środowiska i urządzeń uzdrowiskowych. Charakteryzuje je racjonalne kształtowanie krajobrazu, a ich układ przestrzenny powinien uwzględniać podział na odpowiednie strefy. Jednak na tak zróżnicowanym obszarze niezwykle trudno odseparować od siebie podobszary ciszy i rekreacji oraz zapobiec przenikaniu hałasu pomiędzy nimi.

\section{Park zdrojowy w Inowrocławiu}

Z punktu widzenia podjętej tematyki badań, interesujące są zagadnienia opisujące hałas występujący na terenie parku zdrojowego oraz jego poziom w wydzielonych strefach jednolitego zagospodarowania. Dotyczy to także wzajemnego przenikania hałasów między tymi strefami. Ich ocena w poszczególnych podobszarach parku zdrojowego, jest celem niniejszych rozważań. Podjęcie się takiej analizy uzasadnia fakt, że dostępna literatura nie opisuje ściśle tej problematyki, lecz w większości skupia się na pomiarach hałasu komunikacyjnego, przemysłowego i lotniczego. Szczególnie analizowany jest wpływ hałasu na człowieka i jego środowisko [Barber i inni, 2010; Brambilla, Maffei, 2006; Votsi i inni, 2012]. Konkluzje z takich analiz, stwierdzające np. nieuciążliwość hałasu, bazują najczęściej na porównaniu wyznaczonej pomiarem wartości lokalnego hałasu z wartościami określonymi w normach. Taką ocenę, pomijającą indywidualne odczucia hałasu przez osoby przebywające na ocenianym obszarze, należy także uznać za spore uproszczenie zagadnienia.

Inowrocław jest miastem położonym w województwie kujawsko-pomorskim, stolicą Kujaw Zachodnich, znajdującym się na Szlaku Piastowskim, w pobliżu szlaków wodnych, w sąsiedztwie historycznego Askaukalis - emporium handlowego z okresu rzymskiego, zlokalizowanego na bursztynowym szlaku. Obecnie miasto pełni funkcje:

- dużej jednostki osadniczej,

- ośrodka przemysłowo-gospodarczego i usługowego o znaczeniu regionalnym,

nażnego węzła komunikacji drogowej i kolejowej,

- ośrodka szkolnictwa zawodowego,

- ośrodka lecznictwa uzdrowiskowego z wydzieloną dzielnicą uzdrowiskową.

Na zachód od centrum, które zachowało zabytkowy średniowieczny układ urbanistyczny z prostokątnym rynkiem i licznymi zabytkami sztuki sakralnej, znajduje się wyodrębniona dzielnica uzdrowiskowa z Parkiem Solankowym, tężnią i urządzeniami rekreacyjno-sportowymi (Rys. 2.) [Operat Uzdrowiskowy, 2008]. 


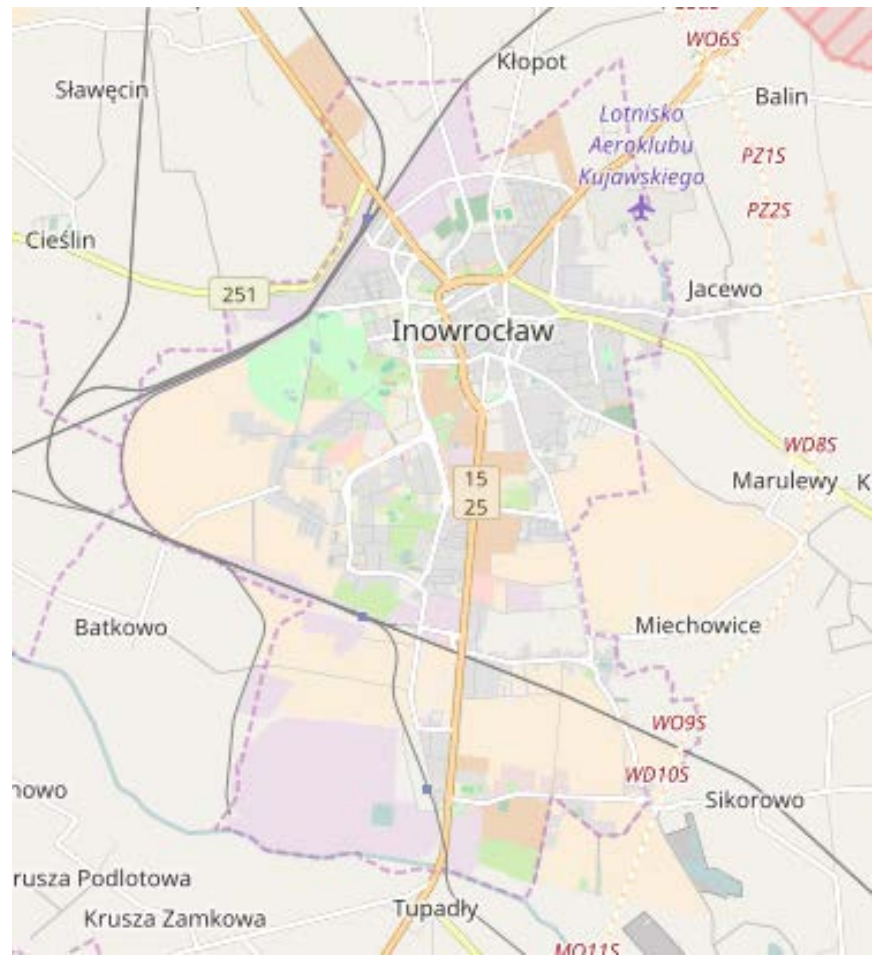

Ryc. 2. Mapa miasta Inowrocławia [https://www. openstreetmap.org/\#map=12/52.7765/18.2617]

Uzdrowisko Inowrocław powstało w 1875 roku. Początkowo Ogród Zdrojowy (Solanki I) zajmował obszar 5 ha, obecnie jego powierzchnia to około 85 ha, położony na obrzeżu miasta jest funkcjonalnie zagospodarowany i przystosowany do działalności leczniczej i rekreacyjnej.

Park Zdrojowy urządzono z myślą o kuracjuszach, umożliwiając spacery alejami i deptakami oraz wypoczynek w powiązaniu z altanami, tężniami, pijalniami wód mineralnych, domami zdrojowymi, zakładami przyrodoleczniczymi i innymi obiektami użyteczności publicznej. Podstawowym przeznaczeniem parku zdrojowego jest stworzenie klimatu wspomagającego leczenie. $Z$ tego względu cały układ przestrzenny miejscowości posiada elementy charakterystyczne tylko dla tego typu obszarów. Podstawą jest zespół przyrodoleczniczy, w którego sąsiedztwie rozciągają się tereny parkowe o dużej wartości kompozycyjnej, estetycznej i kulturowej (Rys. 3, Rys. 4).

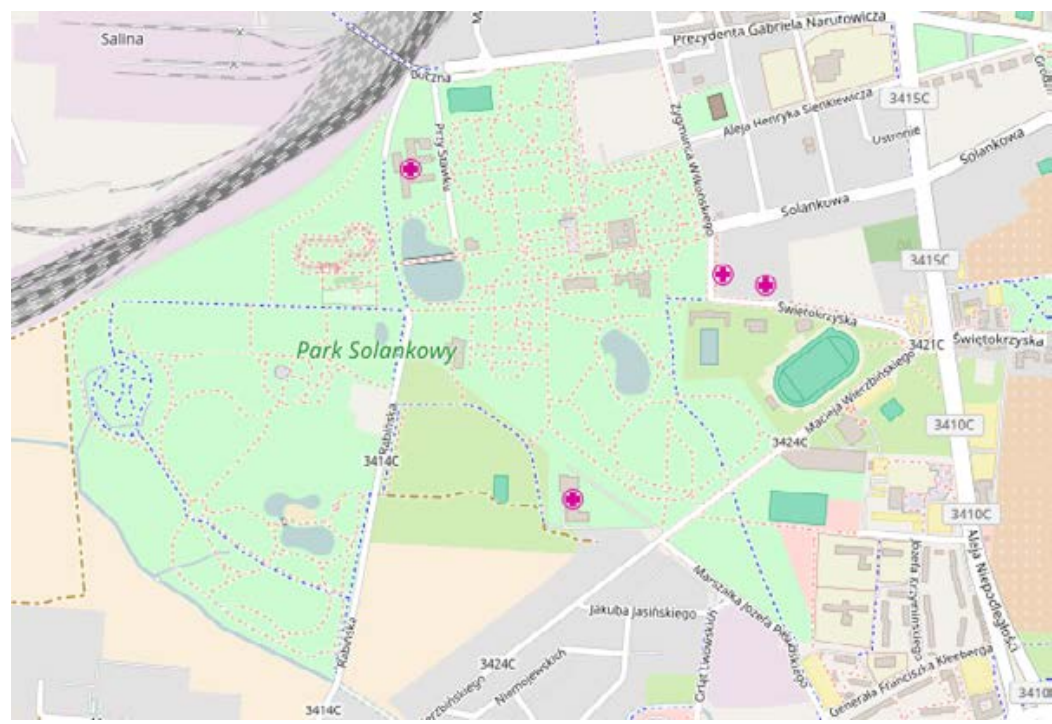

Ryc. 3. Mapa Parku "Solanki” [https://www.openstreetmap. org/\#map=15/52.7917/18.2340] 


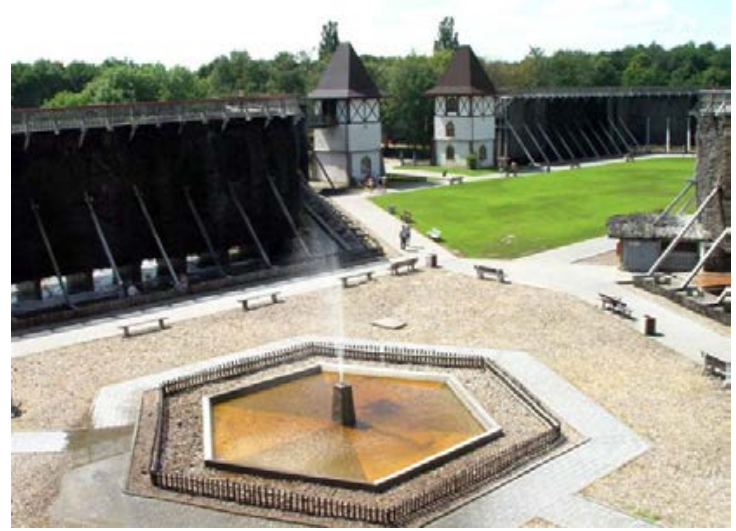

Tężnia solankowa

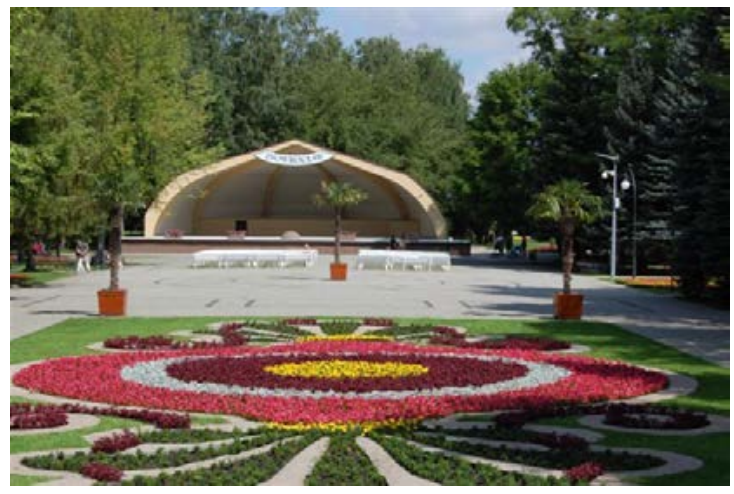

Muszla koncertowa

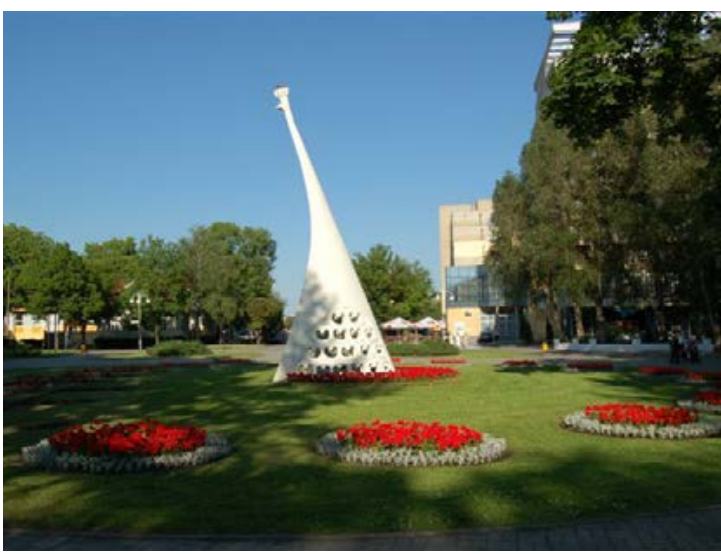

Zegar słoneczny - główne wejście

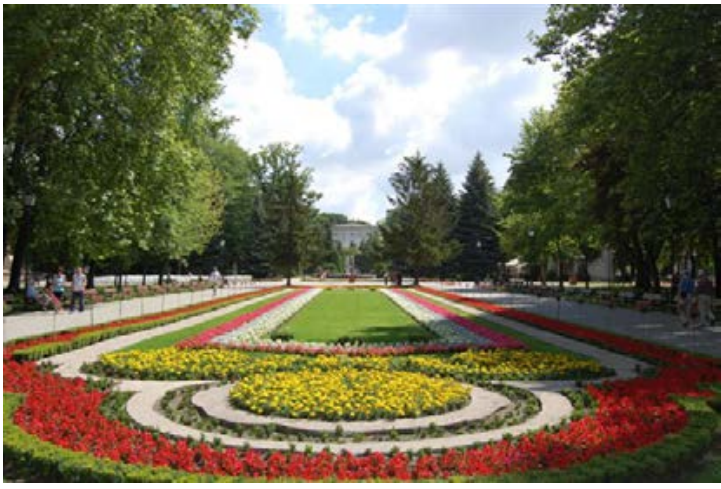

Dywan kwiatowy w głównym ciągu komunikacyjnym parku

Ryc. 4. Fragmenty parku Solanki [www.solanki.pl]

Rewitalizacja pozwoliła na racjonalne zagospodarowanie istniejących i nowych przestrzeni na potrzeby, turystyki uzdrowiskowej (Rys. 5).

W zdrojowisku ważną rolę spełnia organizacja życia towarzyskiego i rozrywkowego. Jednak emisja muzyki na zewnątrz lokali powoduje, iż komfort przebywania w ich sąsiedztwie ulega, dla sporej grupy kuracjuszy, pogorszeniu. Przykład ten uzasadnia stwierdzenie, że większość emitowanego hałasu, na tego typu terenach, wiąże się z działalnością człowieka.

\section{Zapisy dokumentów planistycznych dotyczące planu zagospodarowania parku oraz kierunki polityki gminnej na podstawie obowiązujących aktów prawa}

W polityce przestrzennej gmin, opartej, zgodnie z zapisami ustawy z dnia 27 marca 2003 r. o planowaniu i zagospodarowaniu przestrzennym (Dz.U. z 2016 r. poz. 778, 904, 961, 1250), przede wszystkim na zapisach dokumentów planistycznych, do których należą studium uwarunkowań i kierunków zagospodarowania przestrzennego gminy oraz miejscowy plan zagospodarowania przestrzennego, w ramach których uwzględnia się obszary oraz zasady ochrony środowiska i jego zasobów, ochrony przyrody, krajobrazu, w tym krajobrazu kulturowego i uzdrowisk;

Zgodnie z art. 10 ust. 2 pkt 3 ustawy w studium uwarunkowań i kierunków zagospodarowania przestrzennego, jako dokumencie kształtującym kierunki polityki przestrzennej gminy, uwzględnia się uwarunkowania wynikające w szczególności z dotychczasowego przeznaczenia, zagospodarowania i uzbrojenia terenu oraz ze stanu ładu przestrzennego. 


\section{Schemat Parku Zdrojowego miasta Inowrocław}

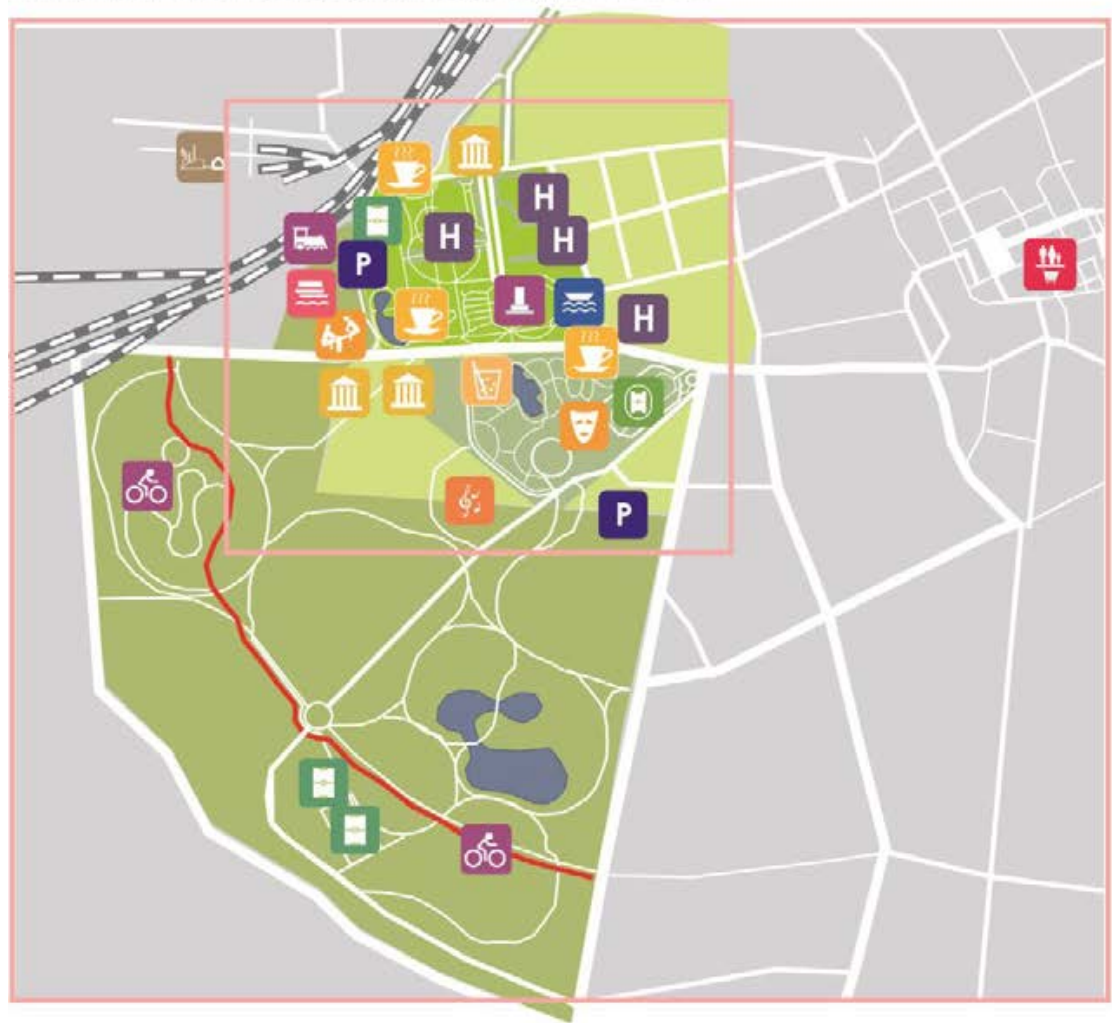

legenda

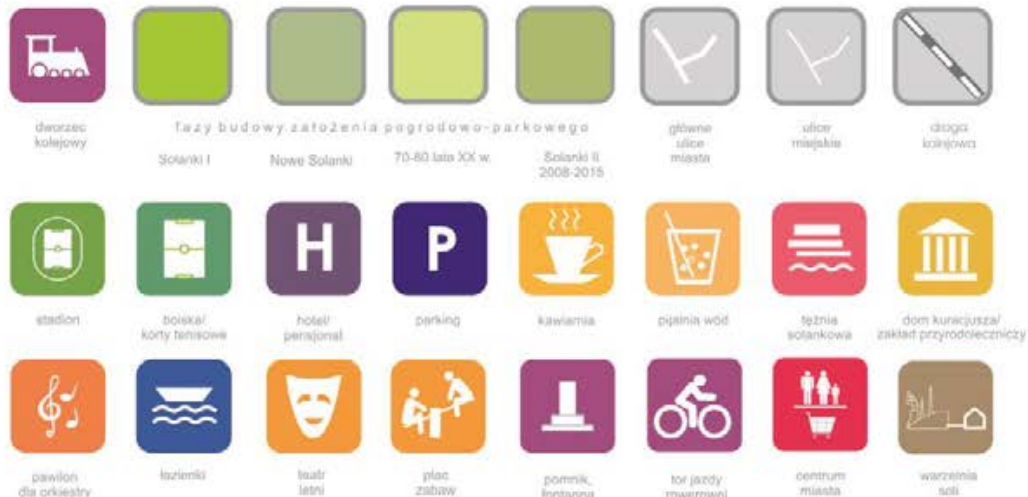

Ryc. 5. Park zdrojowy z wykazem funkcji umiejscowionych na jego terenie

Na podstawie art. 15 ust. 2 ustawy, w planie miejscowym określa się między innymi: zasady ochrony i kształtowania ładu przestrzennego, zasady ochrony środowiska, przyrody i krajobrazu, zasady kształtowania krajobrazu, zasady ochrony dziedzictwa kulturowego i zabytków, w tym krajobrazów kulturowych, oraz dóbr kultury współczesnej, a także wymagania wynikające z potrzeb kształtowania przestrzeni publicznych.

Realizacja inwestycji typu park zdrojowy, wymaga zgodności z kierunkami rozwoju polityki przestrzennej gminy. W ramach ustaleń ww. dokumentów wskazanym jest zaproponowanie rozwiązań mających na celu rozwój, jak również minimalizację skutków ubocznych funkcjonowania tego typu obszaru.

Kontynuacja polityki o której mowa, ma swoje odzwierciedlenie w ustaleniach przyjętych przez Radę Miejską w Inowrocławiu uchwałą nr XVII/230/2011 z dnia 22 grudnia 2011 r. w sprawie uchwalenia statutu Uzdrowiska Inowrocław (Dz. Urz. Woj. Kujawsko-Pomorskiego z dnia 9 stycznia 2012 r. poz. 4). Na mocy powyższego 
dokumentu przyjęto założenia, dla obszaru o powierzchni 84 ha, w ramach którego zinwentaryzowano 5500 drzew i ok. $42000 \mathrm{~m}^{2}$ krzewów:

- zakaz czynności określonych w art. 38a ustawy o lecznictwie uzdrowiskowym, uzdrowiskach i obszarach ochrony uzdrowiskowej oraz o gminnych uzdrowiskach,

- wskazano miejsca prowadzenia punktów sprzedaży pamiątek na obszarze parku uzdrowiskowego w strefie "A",

- w strefie "A", gdzie odbywa się lecznictwo uzdrowiskowe:

a) procentowy udział terenów zieleni - nie mniej niż $65 \%$ powierzchni strefy,

a) minimalna powierzchnia nowo wydzielanych działek - w granicach $1000 \mathrm{~m}^{2}$,

- w strefie "B", stanowiącej otulinę strefy "A":

a) procentowy udział terenów zieleni - nie mniej niż 50\% powierzchni strefy,

b) minimalna powierzchnia nowo wydzielanych działek - w granicach $500 \mathrm{~m}^{2}$,

- w strefie "C":

a) procentowy udział terenów zieleni - nie mniej niż 45\% powierzchni strefy,

b) minimalna powierzchnia nowo wydzielanych działek:

- siedliskowych $-200 \mathrm{~m}^{2}$,

- rekreacyjnych $-500 \mathrm{~m}^{2}$,

- pensjonatowych $-1000 \mathrm{~m}^{2}$,

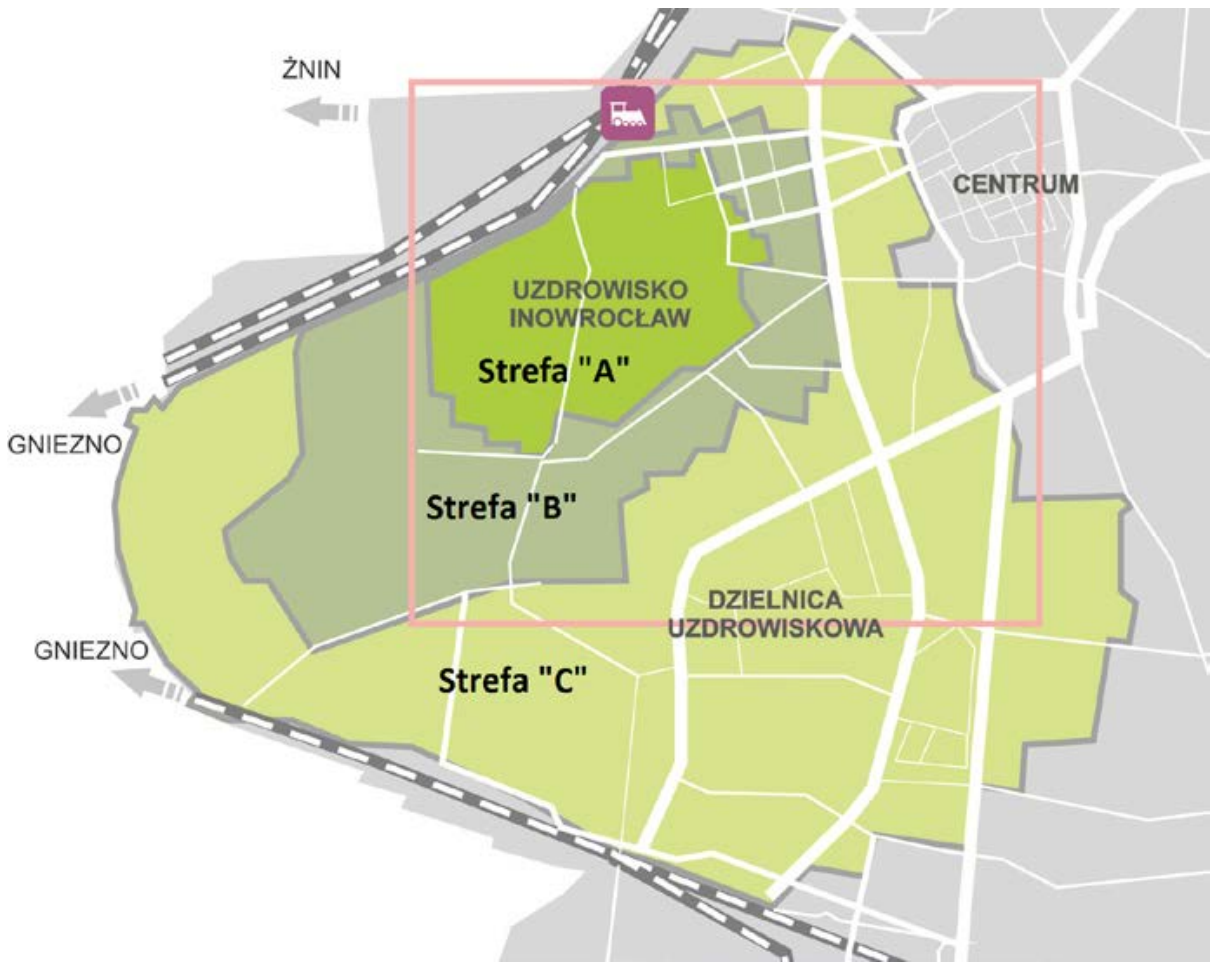

Ryc. 6. Mapa parku z zaznaczonymi strefami uzdrowiskowymi

Uchwałą nr XXXII/461/2013 z dnia 22 kwietnia 2013 r. Rada Miejska Inowrocławia przyjęła miejscowy plan zagospodarowania przestrzennego Miasta Inowrocławia dla terenu w rejonie ulic: Świętokrzyskiej, Prezydenta Franklina Roosevelta, Solankowej i Zygmunta Wilkońskiego (Dz. Urz. Woj. Kujawsko - Pomorskiego z dnia 16 maja 2013 r. poz. 1970). Na podstawie $\S 5$ ust. 5 pkt 4 oraz ust. 8 ww. uchwały na terenie usług zdrowia , w strefie "A" ochrony uzdrowiskowej przyjęto wskaźnik powierzchni zabudowy - maksymalnej 35\% powierzchni działki, w strefie "B" ochrony uzdrowiskowej wskaźnik ten kształtowany jest na poziomie $50 \%$ powierzchni działki. na terenie obu stref obowiązują zakazy określone przepisami odrębnymi

Analizując treść dokumentów polityki lokalnej przyjąć należy iż ich treść w żaden sposób nie odnosi się do problemu bezpieczeństwa akustycznego terenów uzdrowiskowych. Powyższy problem należałoby rozpatrywać 
w ramach dokumentów planistycznych w zakresie zapisów wskazujących na ukształtowanie i sposób zagospodarowania oraz wykorzystania przestrzeni, jak również wykorzystanych nawierzchni w ramach systemów komunikacyjnych.

\section{Podsumowanie i wnioski}

Park Zdrojowy w Inowrocławiu jest obszarem wielofunkcyjnym, skupiającym na swoim terenie obiekty związane z lecznictwem uzdrowiskowym, rozrywką, rekreacją i wypoczynkiem. Ta różnorodność ma swoje odzwierciedlenie w programie użytkowym parku. Analizując dynamikę związaną z rozwojem parku, można spostrzec że obok obszarów cichych występują te o większym hałasie, co wpływa niekorzystnie na ogólny klimat akustyczny parku. Najbardziej dynamicznym okresem, w użytkowaniu parku, jest niewątpliwie sezon letni, w którym nagromadzenie bodźców dźwiękowych jest największe, a klimat akustyczny badanego terenu kształtują wszystkie rodzaje hałasu tam występujące. Należałoby zatem postawić pytanie: „czy hałas, występujący na terenie analizowanego obiektu, a pochodzący od hałasujących dzieci, muzyki, gwaru z lokali rozrywkowych lub gwaru z obiektów sportowych można uznać za uciążliwy?" Jeżeli tak, to zapisy dokumentów kształtujących kierunki polityki przestrzennej gminy, takie jak miejscowy plan zagospodarowania przestrzennego, wydają się odpowiednimi do wskazania działań mających na celu minimalizację skutków ubocznych przestrzeni uzdrowiskowych o charakterze zdrojowym, rozpatrywanych w kategorii obiektów ochrony zdrowia.

Przestrzeń parkową charakteryzuje przenikanie hałasów, dlatego też należy zwrócić uwagę na konieczność rozdzielania stref cichych od głośnych strefami neutralnymi. Uwaga ta, będąca przede wszystkim zaleceniem dotyczącym projektowania układów przestrzennych nowych parków, w przypadku "Solanek" może być zastąpiona wprowadzeniem przegród akustycznych w jej starszej części. Budowa przegród inżynierskich, ze względów estetycznych, wymaga kształtowania terenu i nasadzeń tak, aby grawitacyjny spływ mas powietrza nie był zakłócony i nie naruszył naturalnej wentylacji parku. Wyciszenia wymagają ścieżki i drogi w parku, które jako istniejąca infrastruktura powinny zostać poddane wymianie nawierzchni. Kierunek prowadzonej przez miasto Inowrocław polityki kształtowania obszaru dzielnicy zdrojowej powinien być zapisany w dokumentach prawa lokalnego uniemożliwiając wprowadzanie niekorzystnych zmian zagospodarowania przestrzennego, także w formie użytych materiałów budowlanych i nawierzchniowych.

Zaznaczyć jednak należy, że stwierdzenie o uciążliwości akustycznej występującej na terenie parku, nie musi pokrywać się z rozkładem hałasu określonym na podstawie pomiarów. Osoby przebywające na terenie parku mogą bowiem zwracać uwagę na hałas, którego nie bierze się pod uwagę w ustaleniach normowych. Pełną ocenę tych odczuć można uzyskać na podstawie badań sondażowych osób przebywających na tym terenie. Dopiero one mogą stanowić podstawę do określenia subiektywnej uciążliwości odbieranego hałasu.

Brak w dokumentach planistycznych gminy, w tym w miejscowym planie zagospodarowania przestrzennego, zapisów dopuszczających określone sposoby zagospodarowania i wykorzystania przestrzeni parku mające wpływ na jakość akustyczną ww. przestrzeni, wydaje się niewykorzystanym narzędziem.

\section{Bibliografia}

[1] Aletta F., Kang J., 2015, Soundscape approach integrating noise mappingtechniques: A case study in Brighton, UK. Noise Mapping, 2(1) http://dx.doi.org/10.1515/noise-2015-0001

[2] Barber J.R., Crooks K.R., Fristup K.M., 2010, The costs of chronic noise exposure for terrestrial organisms, Trends in Ecology \& Evolution, 25 (3) (2010), pp. 180-189

[3] Brambilla G., Maffei L., 2006, Responses to noise in urban parks and in rural quiet areas, Acta Acustica united with Acustica, 92 (6) (2006), 881-886

[4] Corburn J., 2009, Toward the healthy city: people, places, and the politics of urbanplanning. Cambridge, Massachusetts: MIT Press. http://dx.doi.org/10.1111/j.1468-2427.2011.01040 3.x

[5] Dyrektywa 2002/49/WE Parlamentu Europejskiego i Rady z dnia 25 czerwca 2002r. odnosząca się do oceny i zarządzania poziomem hałasu w środowisku

[6] Engel Z., 2001, Ochrona środowiska przed drganiami i hałasem. Wydawnictwa Naukowe PWN, Warszawa 
[7] Genuit K., Fiebig A., 2006, Psychoacoustics and its benefit for the soundscape approach. Acta Acustica United with Acustica, 92, 952-958.

[8] Genuit, K., Schulte-Fortkamp, B., \& Fiebig, A., 2008, Psychoacoustic mapping within the soundscape approach. In Proceeding of internoise, pp.594-606.

[9] Hao Y., Kang J., Krijnders, J., 2015, Integrated effects of urban morphology on birdsong loudness and visibility of green areas. Landscape and Urban Planning,137, 149-162. http://dx.doi.org/10.1016/j.landurbplan.2015.01.006

[10] Honga J., Jeon J., 2017, Exploring spatial relationships among soundscape variables in urbanareas: A spatial statistical modelling approach, Landscape and Urban Planning 157 (2017) 352-364

[11] Lipowczan A., 2001., Podstawy normalizacji hałasu w środowisku. AURA 9/2001

[12] Liu J., Kang J., Luo T., Behm H., Coppack, T., 2013, Spatio temporal variability of soundscapes in a multiple functional urban area. Landscape and Urban Planning, 115, pp. 1-9. http://dx.doi.org/10.1016/j.landurbplan.2013.03.008

[13] Liu J., Kang J., Behm H., 2014, Birdsong as an element of the urban sound environment: A case study concerning the area of Warnemünde in Germany. Acta Acustica United with Acustica, 100 (3), 458-466. http://dx.doi.org/10.3813/AAA.918726

[14] Marquis-Favre C., Premat E., Aubree D., 2005, Noise and its effect - A review on qualitative aspect of sound. Part II: Noise and annoyance. Acta Acoustica United With Acoustica, 91, 626-642.

[15] Obwieszczenie Ministra Środowiska z dnia 15 października 2013r. w sprawie ogłoszenia jednolitego tekstu rozporządzenia Ministra Środowiska w sprawie dopuszczalnych poziomów hałasu w środowisku (Dz. U. z 2014, poz. 112)

[16] Operat Uzdrowiskowy. Uzdrowisko Inowrocław. Województwo kujawsko-pomorskie. 2008

[17] Przesmycka N., 2015, Metody kreowania tymczasowych przestrzeni publicznych, Teka Kom. Arch. Urb. Stud. Krajobr. - Ol Pan, 2015, 4

[18] Seidman M. Standring R., 2010, Noise and quality of life. International Journal of Environmental Research and Public Health, 7, 3730-3738.

[19] http://dx.doi.org/10.3390/ijerph7103730

[20] Sztubecka M., Skiba M., 2016, Noise level arrangement in determined zones of homogenous development of green areas on the example of the spa park in Inowrocław, Open Engineering. Volume 6, Issue 1, ISSN (Online) 2391-5439, DOI: 10.1515/eng-2016-0077

[21] Uchwała nr XVII/230/2011 z dnia 22 grudnia 2011r. Rady Miejskiej Inowrocławia w sprawie uchwalenia statutu Uzdrowiska Inowrocław (Dz. Urz. Woj. Kujawsko - Pomorskiego z dnia 9 stycznia 2012r. poz. 4)

[22] Uchwała nr XXXII/461/2013 z dnia 22 kwietnia 2013r. Rada Miejska Inowrocławia w sprawie miejscowego planu zagospodarowania przestrzennego Miasta Inowrocławia dla terenu w rejonie ulic: Świętokrzyskiej, Prezydenta Franklina Poosevelta, Solankowej i Zygmunta Wilkońskiego (Dz. Urz. Woj. Kujawsko - Pomorskiego z dnia 16 maja 2013r. poz. 1970)

[23] Ustawa z dnia 27 kwietnia 2001r. - Prawo ochrony środowiska (Dz. U. z 2016 r. poz. 672, 831, 903, 1250, 1427)

[24] Ustawa z dnia 28 lipca 2005 r. o lecznictwie uzdrowiskowym, uzdrowiskach i obszarach ochrony uzdrowiskowej oraz o gminach uzdrowiskowych (Dz. U. z 2016 r. poz. 879, 960)

[25] Ustawa z dnia 27 marca 2003r. o planowaniu i zagospodarowaniu przestrzennym (Dz. U. z 2016r. poz. 778, 904, 961, 1250)

[26] World Health Organization Guidelines for Community Noise. 2000, in: WHO-Expert Task Force Meeting, Held in London, UK

[27] Votsi N.E.P., Drakou E.G., Mazaris A.D., Kallimanis A.S., Pantis J. D., 2012, Distance-based assessment of open country Quiet Areas in Greece, Landscape and Urban Planning, 01/2012; 104:279-288

[28] www.solanki.pl

[29] www.openstreetmap.org/\#map=12/52.7765/18.2617

[30] www.openstreetmap.org/\#map =15/52.7917/18.2340 


\title{
Safe soundscape in the spa park based on its development plan
}

\begin{abstract}
The areas of human activity are threatened areas occurrence of one of the most nuisance environmental factors - noise. This nuisance refers, in particular, the urban agglomerations. The noise has a negative impact on human health, reduces productivity, makes it difficult to relax and adversely affects the concentration. An indicator of the noise, is a logarithmic measure of sound level - in decibels $(\mathrm{dB})$. Depending on the function and purpose of the area, the law defines the limits of noise levels. They comprise in the range of so-called acoustic comfort.

Proper location and design of the green areas has an impact on the comfort of rest. Planning documents, as local law, indicating the purpose of such areas are the basis for their utility program and development. The relevant provisions of development plan allow for a rational form of space.

The aim of this article is to pay attention to the problem of noise that occurs outside the interval noticeable comfort and assessment of the possibilities offered by this type of documents in relation to the existing notation (in terms of people sound security staying in these type of areas).
\end{abstract}

Keywords: soundscape, environment design, noise, green area, development plan 